DOI: https://doi.org/10.24127/ajpm.v10i3.3968

\title{
PENELITIAN IMPLEMENTASI PEMBELAJARAN MATEMATIKA BAGI ANAK BERKEBUTUHAN KHUSUS DI INDONESIA
}

\author{
Ragil Fitriani $^{1}$, Rully Charitas Indra Prahmana ${ }^{2}$ \\ ${ }^{1,2}$ Universitas Ahmad Dahlan, Yogyakarta, Indonesia \\ E-mail: $\quad$ ragil.fitriani99@gmail.com ${ }^{1)}$ \\ $\underline{\text { rully.indra@mpmat.uad.ac.id }}^{2 *)}$
}

Received 12 July 2021; Received in revised form 12 September 2021; Accepted 20 September 2021

\begin{abstract}
Abstrak
Sejumlah penelitian terkait implementasi pembelajaran matematika pada anak berkebutuhan khusus (ABK) telah banyak dilakukan di Indonesia dan terpublikasi dalam jurnal-jurnal nasional terakreditasi. Namun, belum ada survei artikel mengenai penelitian-penelitian implementasi pembelajaran matematika pada ABK di Indonesia. Sehingga, tujuan dari penelitian ini adalah untuk mengklasifikasikan seluruh penelitian tersebut ke dalam beberapa kategori yang berhubungan dengan penelitian implementasi pembelajaran matematika pada ABK di Indonesia. Penelitian ini menggunakan metode Systematic Literature Review (SLR) yang digunakan untuk mengindentifikasi, mengkaji, mengevaluasi, dan menafsirkan penelitian-penelitian pada topik implementasi pembelajaran matematika pada ABK di Indonesia. Data yang digunakan berasal dari 17 artikel yang terdapat dalam 13 jurnal pendidikan matematika yang telah terakreditasi oleh Kementrian Riset, Teknologi, dan Pendidikan Tinggi Republik Indonesia pada kategori Sinta 1 dan 2. Hasil penelitian ini mengelompokkan seluruh artikel yang di analisis ke dalam lima kategori, yaitu subjek, jenjang pendidikan, materi, kemampuan siswa, dan metode yang digunakan dalam penelitian-penelitian tersebut. Hasil ini berkontribusi dalam memberikan informasi yang komprehensif terkait tren penelitian implementasi pembelajaran matematika pada ABK di Indonesia, sehingga nantinya dapat menjadi rekomendasi dan ide awal dalam penelitian implementasi pembelajaran matematika bagi ABK selanjutnya.
\end{abstract}

Kata kunci: anak berkebutuhan khusus; pembelajaran matematika; jurnal terakreditasi peringkat 1 dan 2; systematic literature review

\begin{abstract}
Several studies related to implementing mathematics learning in Children with Special Needs have been widely carried out in Indonesia and published in accredited national journals. However, there has been no article survey on research on mathematics learning for children with special needs in Indonesia. Thus, the purpose of this study is to classify all of these studies into several categories related to research on the implementation of mathematics learning in children with special needs in Indonesia. This study uses the Systematic Literature Review (SLR) method, which is used to identify, review, evaluate, and interpret research on implementing mathematics learning for children with special needs in Indonesia. The data used comes from seventeen articles contained in thirteen mathematics education journals that have been accredited by the Ministry of Research, Technology and Higher Education of the Republic of Indonesia in the Sinta 1 and 2 categories. The results of this study grouped all analyzed articles into five categories, such as subject, level of education, topic, student abilities, and research methods used in these studies. It also contributes comprehensive information about research trends in implementing mathematics learning for children with special needs in Indonesia. Later, they can become recommendations and initial ideas in research on implementing mathematics teaching and learning for children with special needs.
\end{abstract}

Keywords: children with special needs; mathematics learning; accredited journal in level 1 and 2; systematic literature review

This is an open access article under the Creative Commons Attribution 4.0 International License 


\section{PENDAHULUAN}

Pendidikan merupakan sebuah langkah dalam rangka mencerdaskan kehidupan bangsa (Simatupang \& Yuhertiana, 2021). Pendidikan merupakan kebutuhan dasar bagi setiap manusia untuk mengembangkan kemampuan, membentuk watak, serta mewujudkan peradaban bangsa yang bermartabat (Sujana, 2019). Selanjutnya, Undang-Undang Republik Indonesia Nomor 20 Tahun 2003 Pasal 5, menyatakan bahwa: (1) Setiap warga negara mempunyai hak yang sama untuk memperoleh pendidikan yang bermutu; (2) Warga negara yang memiliki kelainan fisik, emosional, mental, intelektual, dan/atau sosial berhak memperoleh pendidikan khusus. Oleh karena itu, kesempatan dalam memperoleh pendidikan yang bermutu merupakan hak yang harus dipenuhi oleh negara, serta berkewajiban untuk merangkul anak-anak dari berbagai kalangan, tanpa terkecuali bagi Anak Berkebutuhan Khusus (ABK).

Desiningrum (2016) menjelaskan bahwa ABK merupakan anak yang mengalami keterbatasan atau keluarbiasaan, baik pada fisik, mentalintelektual, sosial, maupun emosional, yang berpengaruh signifikan dalam proses pertumbuhan atau perkembangannya, dibandingkan dengan anak-anak lain pada usia yang sama. Berdasarkan data yang dikeluarkan oleh Kementerian Pendidikan dan Kebudayaan (Kemendikbud) tahun 2017 yang termuat di https://www.kemdikbud.go.id, menunjukkan bahwa dari 1,6 juta ABK di Indonesia, hanya $18 \%$ yang sudah mendapatkan layanan pendidikan inklusi. Sekitar 115 ribu ABK bersekolah di SLB, sedangkan ABK yang bersekolah di sekolah reguler pelaksana sekolah inklusi berjumlah sekitar 299 ribu. Hal ini menunjukkan bahwa siswa ABK belum mendapatkan perhatian sebagaimana yang diterima oleh siswa non ABK.

Salah satu mata pelajaran wajib bagi siswa ABK adalah matematika. Selanjutnya, Ramdani (2006) menjelaskan bahwa dalam dunia ilmu pengetahuan, matematika merupakan dasar yang kuat, karena tidak terdapat satu cabang ilmu yang tidak melibatkan matematika. Namun, melihat kenyataan di lapangan, pelajaran matematika dikategorikan sebagai pelajaran yang dianggap sulit dan kurang digemari oleh sebagian siswa (Aziz, Sugiman, \& Prabowo, 2015). Hal ini menjadi tantangan tersendiri bagi para Pendidik untuk mengajarkan matematika kepada siswa ABK.

Sejumlah penelitian mengenai implementasi pembelajaran matematika pada ABK telah banyak dilakukan di Indonesia dan terpublikasi di sejumlah jurnal nasional terakreditasi, diantaranya, penelitian pengembangan media pembelajaran bagi siswa $\mathrm{ABK}$ (Wahyuni, Hiltrimartin, \& Zulkardi, 2008; Sumalasia, Suarsana, \& Astawa, 2020; Sari, Pratama, \& Permatasari, 2020; Ariyantika, Farida, \& Rakhmawati, 2019), implementasi suatu strategi, metode, model, dan pembelajaran matematika pada siswa ABK (Suningsih \& Arnidha, 2017; Nuari, Prahmana, \& Fatmawati, 2019; Sabaruddin, dkk. 2020). Selanjutnya, Aziz, Sugiman, dan Prabowo (2015) meneliti tentang analisis proses pembelajaran matematika pada anak berkebutuhan khusus (ABK) slow learner di kelas inklusif SMP Negeri 7 Salatiga. Namun, sejumlah penelitian sebelumnya masih berfokus kepada memberikan suatu perlakuan dan kemudian melihat implikasinya. Sehingga, 
DOI: https://doi.org/10.24127/ajpm.v10i3.3968

penelitian ini berfokus kepada mengelompokkan sejumlah penelitian tersebut dalam bentuk penelitian survei yang mengklasifikasikan sejumlah penelitian terkait implementasi pembelajaran matematika pada siswa ABK di Indonesia pada kategori tertentu.

Penelitian survei terkait penelitian pendidikan matematika di Indonesia, telah didokumentasikan oleh sejumlah peneliti, diantaranya survei penelitian Realistic Mathematics Education (RME) selama 20 tahun terakhir, yang mengelompokkan tujuh kategori, yaitu dominasi artikel RME yang diterbitkan, subjek penelitian RME, topik matematika, kemampuan siswa, istilah RME, dan metode penelitian yang digunakan dalam artikel RME (Prahmana, dkk. 2020) dan survei penelitian terkait The Programme for International Student Assessment (PISA) di Indonesia yang menghasilkan sembilan kategori (Rastuti \& Prahmana, 2021), yang mana kedua penelitian tersebut berkontribusi terhadap penelitian selanjutnya pada topik RME dan PISA. Sehingga, penelitian ini bertujuan untuk menambah khazanah penelitian survei dengan topik kajian yang berbeda, yaitu terkait implementasi pendidikan matematika pada ABK di Indonesia, yang belum pernah diteliti oleh para peneliti sebelumnya.

\section{METODE PENELITIAN}

Metode yang digunakan dalam penelitian ini yaitu Systematic Literature Review (SLR). Calderon dan Ruiz (2015) menjelaskan bahwa SLR merupakan suatu cara identifikasi, evaluasi, dan interpretasi seluruh ketersediaan penelitian yang relevan terhadap rumusan masalah maupun area topik yang diteliti. SLR digunakan untuk mengindentifikasi, mengkaji, mengevaluasi, dan menafsirkan seluruh penelitian yang tersedia dengan bidang topik fenomena menarik dengan pertanyaan penelitian tertentu yang relevan (Lusiana \& Suryani, 2014; Yunanto \& Rochimah, 2017).

Proses penelitian ini dimulai dengan melakukan review serta mengidentifikasi artikel pada jurnal secara sistematis sesuai dengan proses dan langkah-langkah yang telah ditetapkan. Selanjutnya, artikel yang di review berasal dari 13 jurnal pendidikan matematika dan matematika yang telah terakreditasi oleh Kementrian Riset, Teknologi, dan Pendidikan Tinggi Republik Indonesia pada kategori Sinta 1 dan 2. Adapun sejumlah tahapan yang dilakukan untuk mengumpulkan data dalam penelitian ini adalah sebagai berikut.

\section{Proses Pencarian (Search Process)}

Proses pencarian dilakukan untuk memperoleh sumber-sumber yang relevan untuk menjawab Research Question dan referensi terkait lainnya. Proses ini menggunakan search engine dengan situs dari 13 jurnal pendidikan matematika dan matematika yang terakreditasi oleh Kementrian Riset, Teknologi, dan Pendidikan Tinggi Republik Indonesia pada kategori Sinta 1 dan 2. Adapun pemilihan ke-13 jurnal tersebut didasari oleh kualitas artikel yang diterbitkan oleh jurnal-jurnal tersebut. Hal ini dikarenakan ke-13 jurnal tersebut telah terakreditasi di peringkat 1 dan 2 (Kategori Sinta 1 dan Sinta 2), yang merupakan sebuah pencapaian atau indikator suatu jurnal yang baik di Indonesia.

Pada kategori Sinta 1 terdapat Journal on Mathematics Education (JME). Selanjutnya, terdapat tujuh jurnal dalam kategori Sinta 2, yaitu Jurnal Pendidikan Matematika (JPM), Infinity Journal, Jurnal Riset Pendidikan Matematika (JRPM), Beta: 
Jurnal Tadris Matematika, Jurnal Elemen, International Journal on Emerging Mathematics Education (IJEME), Pythagoras: Jurnal Pendidikan Matematika, Jurnal Didaktik Matematika (JDM), Al-Jabar: Jurnal Pendidikan Matematika, JRAMathEdu (Journal of Research and Advances in Mathematics Education), Aksioma: Jurnal Program Studi Pendidikan Matematika, dan Kreano: Jurnal Matematika Kreatif-Inovatif.

\section{Kriteria Batasan dan Pemasukan}

Tahapan ini dilakukan dalam upaya memutuskan apakah data yang diperoleh layak digunakan dalam penelitian SLR atau tidak. Kriteria layak dipilih dalam penelitian ini yaitu, pertama, data berasal dari 13 jurnal pendidikan matematika dan matematika yang terakreditasi oleh Kementrian Riset, Teknologi, dan Pendidikan Tinggi Republik Indonesia pada kategori Sinta 1 dan 2; kedua, data yang digunakan hanya berhubungan dengan penelitian terkait implementasi pembelajaran matematika pada $\mathrm{ABK}$ di Indonesia dalam rentang waktu 14 tahun terakhir (2007-2020).

\section{Kualitas Penilaian}

Pada penelitian SLR, data yang ditemukan dievaluasi berdasarkan pertanyaan kriteria penilaian kualitas, yaitu:

1. Apakah pada artikel menuliskan subjek dalam penelitian implementasi pembelajaran matematika pada ABK (QA1)?

2. Apakah pada artikel menuliskan jenjang pendidikan dalam penelitian implementasi pembelajaran matematika pada ABK (QA2)?

3. Apakah pada artikel menuliskan materi dalam penelitian implementasi pembelajaran matematika pada ABK (QA3)?
4. Apakah pada artikel menuliskan kemampuan siswa yang akan diteliti dalam penelitian implementasi pembelajaran matematika pada $\mathrm{ABK}$ (QA4)?

5. Apakah pada artikel menuliskan metode yang digunakan dalam penelitian implementasi pembelajaran matematika pada $\mathrm{ABK}$ (QA5)?

Kelima pertanyaan tersebut memiliki nilai yaitu "Ya" atau "Tidak". Jika "Ya" maka dituliskan "Y", dan jika "Tidak" maka dituliskan "T". Setelah itu, semua QA dijumlahkan untuk menentukan layak atau tidaknya artikel tersebut. Artikel dikatakan layak apabila jumlah "Y" $\geq 3$ dan "T" $\leq 2$.

\section{Pengumpulan Data}

Data yang dikumpulkan dalam penelitian ini menggunakan data sekunder. Pengumpulan data yang digunakan berupa artikel dari 13 jurnal tentang pendidikan matematika dan matematika yang terakreditasi peringkat tertinggi oleh Kementrian Riset, Teknologi, dan Pendidikan Tinggi pada kategori Sinta 1 dan 2 yang terdapat pada tabel 1. Adapun langkah-langkah dalam pengumpulan data antara lain pertama, mengunjungi situs 13 jurnal pendidikan matematika dan matematika yang telah terakreditasi oleh Kementrian Riset, Teknologi, dan Pendidikan Tinggi pada kategori Sinta 1 dan 2; kedua, klik "Archive" pada pilihan menu yang tersedia; ketiga, membaca judul artikel pada setiap tahunnya; keempat, memilih artikel yang berkaitan dengan pembelajaran matematika bagi ABK.

\section{Analisis Data}

Analisis yang dilakukan terhadap artikel yang telah dikumpulkan yaitu dengan mendata setiap artikel yang 
DOI: https://doi.org/10.24127/ajpm.v10i3.3968

dikumpulkan, kemudian mengklasifikasikan artikel tersebut untuk menunjukkan pertama, subjek yang digunakan dalam penelitianpenelitian implementasi pembelajaran matematika pada ABK di Indonesia; kedua, jenjang pendidikan dalam penelitian-penelitian implementasi pembelajaran matematika pada $\mathrm{ABK}$ di Indonesia; ketiga, materi yang digunakan dalam penelitian-penelitian implementasi pembelajaran matematika pada ABK di Indonesia; keempat, kemampuan siswa yang digunakan dalam penelitian-penelitian terkait implementasi pembelajaran matematika pada ABK di Indonesia; dan kelima, metode yang digunakan dalam penelitian-penelitian implementasi pembelajaran matematika pada ABK di Indonesia.

\section{Penyimpangan Laporan}

Sebagai hasil dari kajian, dilakukan penulisan kembali perubahan pada penyimpangan laporan, yaitu penelitian ini mengidentifikasi subjek, jenjang pendidikan, materi, kemampuan siswa, dan metode apa yang digunakan dalam penelitian, serta menjawab pertanyaan penelitian; dan kedua, mencari dan mengkumpulkan jurnal untuk menjawab rumusan masalah serta memastikan keabsahan informasi yang dibutuhkan.

\section{HASIL DAN PEMBAHASAN}

Hasil dalam proses pencarian dikelompokkan berdasarkan 13 jurnal pendidikan matematika dan matematika yang terakreditasi oleh Kementrian Riset, Teknologi, dan Pendidikan Tinggi Republik Indonesia pada kategori Sinta 1 dan 2. Hasil dari proses pencarian disajikan pada Tabel 1 .
Tabel 1. Pengelompokan Jurnal

\begin{tabular}{|c|c|c|}
\hline No & Nama Jurnal & Jumlah \\
\hline 1 & $\begin{array}{l}\text { Journal on Mathematics } \\
\text { Education (JME) }\end{array}$ & 1 \\
\hline 2 & $\begin{array}{l}\text { Journal Pendidikan } \\
\text { Matematika (JPM) }\end{array}$ & 1 \\
\hline 3 & Infinity Journal & 0 \\
\hline 4 & $\begin{array}{l}\text { Jurnal Riset Pendidikan } \\
\text { Matematika (JRPM) }\end{array}$ & 1 \\
\hline 5 & $\begin{array}{l}\text { Beta: Jurnal Tadris } \\
\text { Matematika }\end{array}$ & 0 \\
\hline 6 & Jurnal Eleman & 0 \\
\hline 7 & $\begin{array}{l}\text { International Journal on } \\
\text { Emerging Mathematics } \\
\text { Education (IJEME) }\end{array}$ & 1 \\
\hline 8 & $\begin{array}{l}\text { Pythagoras: Jurnal } \\
\text { Pendidikan Matematika }\end{array}$ & 1 \\
\hline 9 & $\begin{array}{l}\text { Jurnal Didaktik } \\
\text { Matematika (JDM) }\end{array}$ & 0 \\
\hline 10 & $\begin{array}{l}\text { Al-Jabar: Jurnal } \\
\text { Pendidikan Matematika }\end{array}$ & 3 \\
\hline 11 & $\begin{array}{l}\text { JRAMathEdu (Journal of } \\
\text { Research and Advances } \\
\text { in Mathematics } \\
\text { Education }\end{array}$ & 1 \\
\hline 12 & $\begin{array}{l}\text { Aksioma: Jurnal Program } \\
\text { Studi Pendidikan } \\
\text { Matematika }\end{array}$ & 4 \\
\hline 13 & $\begin{array}{l}\text { Kreano: Jurnal } \\
\text { Matematika Kreatif- } \\
\text { Inovatif }\end{array}$ & 4 \\
\hline & Total & 17 \\
\hline
\end{tabular}

\section{Hasil Kriteria Batasan dan Pemasukan}

Pada hasil dari proses pencarian, terdapat 17 artikel dari sembilan jurnal pendidikan matematika dan matematika yang terakreditasi oleh Kementrian Riset, Teknologi, dan Pendidikan Tinggi Republik Indonesia pada kategori Sinta 1 dan 2. Data yang berupa artikel tersebut memenuhi kriteria batasan dan pemasukan, karena berhubungan dengan penelitian implementasi pembelajaran matematika pada ABK, seperti disajikan pada Tabel 2. 
AKSIOMA: Jurnal Program Studi Pendidikan Matematika

ISSN 2089-8703 (Print)

Volume 10, No. 3, 2021, 1293-1307

ISSN 2442-5419 (Online)

DOI: https://doi.org/10.24127/ajpm.v10i3.3968

Tabel 2. Hasil Kualitas Penilaian (Quality Assessment)

\begin{tabular}{|c|c|c|c|c|c|c|c|c|c|c|}
\hline No & Nama Penulis & Judul & Tahun & $\begin{array}{l}\text { Nama } \\
\text { Jurnal }\end{array}$ & $\begin{array}{c}\mathbf{Q} \\
\mathbf{A 1}\end{array}$ & $\begin{array}{c}\mathbf{Q} \\
\mathbf{A 2}\end{array}$ & $\begin{array}{c}\mathbf{Q} \\
\mathbf{A 3}\end{array}$ & $\begin{array}{c}Q \\
\text { A4 }\end{array}$ & $\begin{array}{c}\text { Q } \\
\text { A5 }\end{array}$ & Hasil \\
\hline 1 & $\begin{array}{l}\text { Laila Fatika Nuari, } \\
\text { Rully Charitas Indra } \\
\text { Prahmana, Irma } \\
\text { Fatmawati }\end{array}$ & $\begin{array}{l}\text { Learning of Division Operation for } \\
\text { Mental Retardations' Student Through } \\
\text { Math Gasing }\end{array}$ & 2019 & JME & $\mathrm{Y}$ & $\mathrm{Y}$ & $\mathrm{Y}$ & $\mathrm{Y}$ & $\mathrm{Y}$ & $\checkmark$ \\
\hline 2 & $\begin{array}{l}\text { Najmi Wahyuni, Cecil } \\
\text { Hiltrimartin, Zulkardi }\end{array}$ & $\begin{array}{l}\text { Pengembangan Materi Pokok Mata } \\
\text { Uang dengan Pendekatan PMRI untuk } \\
\text { Siswa Tunagrahita Ringan Kelas XI di } \\
\text { SLBC Karya Ibu Palembang }\end{array}$ & 2008 & JPM & $\mathrm{Y}$ & $\mathrm{Y}$ & $\mathrm{Y}$ & $\mathrm{T}$ & $\mathrm{Y}$ & $\checkmark$ \\
\hline 3 & $\begin{array}{l}\text { Ai Sadidah, Ariyadi } \\
\text { Wijaya }\end{array}$ & $\begin{array}{l}\text { Developing Mathematics Learning Set } \\
\text { for Special-Needs Junior High School } \\
\text { Student Oriented to Learning Interest } \\
\text { and Achievement }\end{array}$ & 2016 & JRPM & $\mathrm{Y}$ & $\mathrm{Y}$ & $\mathrm{T}$ & $\mathrm{T}$ & $\mathrm{Y}$ & $\checkmark$ \\
\hline 4 & $\begin{array}{l}\text { Sumbaji Putranto, } \\
\text { Marsigit }\end{array}$ & $\begin{array}{l}\text { Is it Effective using Peer Tutoring with } \\
\text { Realistic Mathematics Education } \\
\text { Approach to Improve Slow Learners, } \\
\text { Mathematics Attitudes? }\end{array}$ & 2018 & IJEME & Y & $\mathrm{Y}$ & $\mathrm{T}$ & $\mathrm{Y}$ & $\mathrm{Y}$ & $\checkmark$ \\
\hline 5 & $\begin{array}{l}\text { I Kadek Yasa } \\
\text { Sumalasia, I Made } \\
\text { Suarsana, I Wayan } \\
\text { Puja Astawa }\end{array}$ & $\begin{array}{l}\text { Pengembangan Bahan Ajar Interaktif } \\
\text { Multi Representasi pada Materi } \\
\text { Geometri Kelas VII SMPLB Tunarungu }\end{array}$ & 2020 & $\begin{array}{l}\text { Pythag } \\
\text { oras }\end{array}$ & $\mathrm{Y}$ & $\mathrm{Y}$ & $\mathrm{Y}$ & $\mathrm{T}$ & $\mathrm{Y}$ & $\checkmark$ \\
\hline 6 & $\begin{array}{l}\text { Nanang Supriadi, Rani } \\
\text { Damayanti }\end{array}$ & $\begin{array}{l}\text { Analisis Kemampuan Komunikasi } \\
\text { Matematis Siswa Lamban Belajar }\end{array}$ & 2016 & $\begin{array}{l}\text { Al- } \\
\text { Jabar }\end{array}$ & $\mathrm{Y}$ & $\mathrm{Y}$ & $\mathrm{Y}$ & $\mathrm{Y}$ & $\mathrm{Y}$ & $\checkmark$ \\
\hline 7 & Mujib & $\begin{array}{l}\text { Komunikasi Matematis Siswa } \\
\text { Tunarungu dalam Pembelajaran } \\
\text { Matematika Didasarkan pada Teori } \\
\text { Schoenfeld }\end{array}$ & 2016 & $\begin{array}{l}\text { Al- } \\
\text { Jabar }\end{array}$ & $\mathrm{Y}$ & $\mathrm{Y}$ & $\mathrm{T}$ & $\mathrm{Y}$ & Y & $\checkmark$ \\
\hline 8 & Rany Widyastuti & $\begin{array}{l}\text { Pola Interaksi Guru dan Siswa } \\
\text { Tunanetra SMPLB A Bina Insani } \\
\text { Bandar Lampung }\end{array}$ & 2016 & $\begin{array}{l}\text { Al- } \\
\text { Jabar }\end{array}$ & Y & $\mathrm{Y}$ & $\mathrm{T}$ & $\mathrm{T}$ & $\mathrm{Y}$ & $\checkmark$ \\
\hline 9 & $\begin{array}{l}\text { Sabaruddin, Rosnidar } \\
\text { Mansor, Irfan Rusmar, } \\
\text { Fadila Husna }\end{array}$ & $\begin{array}{l}\text { Student with Special Needs and } \\
\text { Mathematics Learning: A Case Study of } \\
\text { an Autistic Student }\end{array}$ & 2020 & $\begin{array}{l}\text { JRAM } \\
\text { athEdu }\end{array}$ & Y & $\mathrm{Y}$ & $\mathrm{T}$ & $\mathrm{T}$ & $\mathrm{Y}$ & $\checkmark$ \\
\hline 10 & $\begin{array}{l}\text { Nurain Suryadinata, } \\
\text { Nurul Farida }\end{array}$ & $\begin{array}{l}\text { Analisis Proses Berpikir Anak } \\
\text { Berkebutuhan Khusus (ABK) dalam } \\
\text { Menyelesaikan Masalah Matematika di } \\
\text { SMP Inklusi Kota Metro (Studi Kasus } \\
\text { pada Siswa Tunagrahita Ringan) }\end{array}$ & 2016 & $\begin{array}{c}\text { Aksio } \\
\text { ma }\end{array}$ & $\mathrm{Y}$ & $\mathrm{Y}$ & $\mathrm{Y}$ & $\mathrm{Y}$ & $\mathrm{Y}$ & $\checkmark$ \\
\hline 11 & $\begin{array}{l}\text { Ari Suningsih, Yunni } \\
\text { Arnidha }\end{array}$ & $\begin{array}{l}\text { Komunikasi Matematis Siswa } \\
\text { Tunarungu Melalui Model Pembelajaran } \\
\text { Think Pair Share }\end{array}$ & 2017 & $\begin{array}{l}\text { Aksio } \\
\text { ma }\end{array}$ & $\mathrm{Y}$ & $\mathrm{Y}$ & $\mathrm{T}$ & $\mathrm{Y}$ & $\mathrm{Y}$ & $\checkmark$ \\
\hline 12 & $\begin{array}{l}\text { Devi Ariyantika, } \\
\text { Farida, Rosida } \\
\text { Rakhmawati }\end{array}$ & $\begin{array}{l}\text { Pengembangan Pocket Book of } \\
\text { Mathematic pada Siswa Berkebutuhan } \\
\text { Khusus untuk Memfasilitasi } \\
\text { Kemampuan Pemahaman Konsep } \\
\text { Matematis }\end{array}$ & 2019 & $\begin{array}{c}\text { Aksio } \\
\text { ma }\end{array}$ & $\mathrm{Y}$ & $\mathrm{Y}$ & $\mathrm{T}$ & $\mathrm{T}$ & $\mathrm{Y}$ & $\checkmark$ \\
\hline 13 & $\begin{array}{l}\text { Savitri } \\
\text { Wanabuliandari, } \\
\text { Ristiyani, Nuning } \\
\text { Kurniasih }\end{array}$ & $\begin{array}{l}\text { Desain Pengembangan Modul } \\
\text { Matematika Berbasis Santun Berbahasa } \\
\text { untuk Siswa Slow Learner di Sekolah } \\
\text { Dasar }\end{array}$ & 2020 & $\begin{array}{l}\text { Aksio } \\
\text { ma }\end{array}$ & $\mathrm{Y}$ & $\mathrm{Y}$ & $\mathrm{Y}$ & $\mathrm{T}$ & $\mathrm{Y}$ & $\checkmark$ \\
\hline 14 & $\begin{array}{l}\text { Alfian Nur Aziz, } \\
\text { Sugiman, Ardhi } \\
\text { Prabowo }\end{array}$ & $\begin{array}{l}\text { Analisis Proses Pembelajaran } \\
\text { Matematika pada Anak Berkebutuhan } \\
\text { Khusus (ABK) Slow Learner di Kelas } \\
\text { Inklusif SMP Negeri } 7 \text { Salatiga }\end{array}$ & 2015 & Kreano & $\mathrm{Y}$ & $\mathrm{Y}$ & $\mathrm{T}$ & $\mathrm{T}$ & $\mathrm{Y}$ & $\checkmark$ \\
\hline 15 & $\begin{array}{l}\text { Ranu Fitra Pradhitya, } \\
\text { Tri Nova Hasti } \\
\text { Yunianta, Novisita } \\
\text { Ratu }\end{array}$ & $\begin{array}{l}\text { Profil Berpikir Geometri Siswa } \\
\text { Tunagrahita berdasarkan Tingkatan Van } \\
\text { Hiele di SMPLB Negeri Salatiga }\end{array}$ & 2017 & Kreano & $\mathrm{Y}$ & $\mathrm{Y}$ & $\mathrm{Y}$ & $\mathrm{Y}$ & $\mathrm{Y}$ & $\checkmark$ \\
\hline 16 & $\begin{array}{l}\text { Lisna Sari, Ryan } \\
\text { Angga Pratama, Besse } \\
\text { Intan Permatasari }\end{array}$ & $\begin{array}{l}\text { Media Pembelajaran Puzzle Angka dan } \\
\text { Corong Angka (PANCORAN) Bagi } \\
\text { Anak Berkebutuhan Khusus (ABK) }\end{array}$ & 2020 & Kreano & $\mathrm{Y}$ & $\mathrm{Y}$ & $\mathrm{Y}$ & $\mathrm{T}$ & $\mathrm{Y}$ & $\checkmark$ \\
\hline 17 & $\begin{array}{l}\text { Nurfaidah, Sudirman, } \\
\text { dan Mellawaty }\end{array}$ & $\begin{array}{l}\text { Bagaimanakah Cara Siswa Tunagrahita } \\
\text { Ringan Menyelesaikan Soal Operasi } \\
\text { Hitung Pembagian?: Exploratory Case } \\
\text { Study dalam menggunakan Media } \\
\text { Kotak Puzzle Geometri }\end{array}$ & 2020 & Kreano & Y & $\mathrm{Y}$ & $\mathrm{Y}$ & $\mathrm{T}$ & $\mathrm{Y}$ & $\checkmark$ \\
\hline
\end{tabular}


DOI: https://doi.org/10.24127/ajpm.v10i3.3968

\section{Tren Penelitian Implementasi Pendidikan Matematika pada ABK di Indonesia}

Publikasi artikel dalam jurnal pendidikan matematika dan matematika yang terakreditasi peringkat tertinggi oleh Kementrian Riset, Teknologi, dan Pendidikan Tinggi Republik Indonesia pada kategori Sinta 1 dan 2 terkait penelitian implementasi pembelajaran matematika pada $\mathrm{ABK}$, pertama kali dilakukan oleh Wahyuni, Hiltrimartin, dan Zulkardi (2008) yang dipublikasikan di Jurnal Pendidikan Matematika (JPM) dengan judul penelitian "Pengembangan Materi Pokok Mata Uang dengan Pendekatan PMRI untuk Siswa Tunagrahita Ringan Kelas XI di SLBC Karya Ibu Palembang".

Selanjutnya, penelitian implementasi pembelajaran matematika pada ABK tidak mengalami penambahan publikasi, sampai pada tahun 2015 Jurnal Kreano mempublikasikan sebuah artikel. Pada tahun 2016, penelitian implementasi pembelajaran matematika pada $\mathrm{ABK}$ mengalami peningkatan dengan publikasi dari JRPM, Jurnal Aksioma, dan Jurnal Al-Jabar, dengan total 5 artikel. Pada tahun 2017, Jurnal Aksioma dan Jurnal Kreano kembali mempublikasikan artikel. IJEME mempublikasikan artikel terkait penelitian implementasi pembelajaran matematika pada ABK pada tahun 2018. Jurnal Aksioma kembali mempublikasikan artikel pada tahun 2019. Di tahun yang sama, JME mempublikasikan sebuah artikel terkait penelitian implementasi pembelajaran matematika pada ABK.

Pada tahun 2020, Pythagoras dan JRAMathEdu mempublikasikan sebuah artikel. Selain itu, Jurnal Aksioma dan Jurnal Kreano kembali mempublikasi- kan artikel terkait penelitian implementasi pembelajaran matematika pada ABK. Hasil survei dari 13 jurnal pendidikan matematika dan matematika yang terakreditasi peringkat tertinggi oleh Kementrian Riset, Teknologi, dan Pendidikan Tinggi Republik Indonesia pada kategori Sinta 1 dan 2, ditemukan 9 jurnal yang mempublikasikan artikel terkait penelitian terkait siswa ABK di Indonesia.

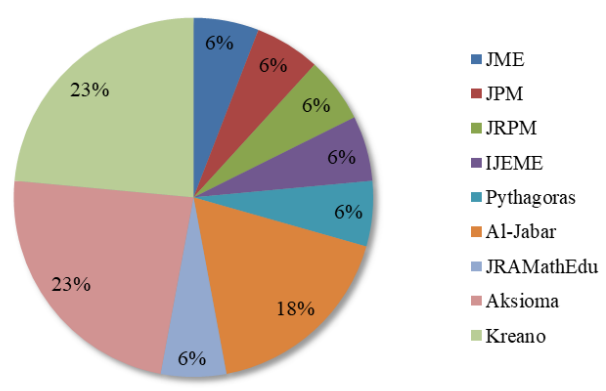

Gambar 1. Persentase artikel penelitian implementasi pembelajaran matematika pada ABK di setiap jurnal

Berdasarkan data dari 9 jurnal tersebut, Jurnal Aksioma dan Jurnal Kreano cukup konsisten dalam mempublikasikan penelitian implementasi pembelajaran matematika pada ABK. Dominasi artikel terdapat pada Jurnal Aksioma dan Jurnal Kreano sebesar 23\%, dilanjutkan dengan Jurnal Al-Jabar sebesar $18 \%$. Sedangkan, 6 jurnal lainnya memiliki persentase yang sama yaitu sebesar 6\%. Diagram lingkaran dari persentase artikel penelitian implementasi pembelajaran matematika pada ABK di setiap jurnal, disajikan pada Gambar 1.

\section{Subjek dalam Penelitian Implementasi Pembelajaran Matematika pada ABK di Indonesia}

Seluruh data berupa artikel hasil penelitian yang dikumpulkan dan dianalisis, menunjukkan bahwa subjek yang digunakan dalam penelitian- 
penelitian tersebut, diantaranya siswa tunagrahita, slow learner, tunarungu, autis, tunanetra, dan mathematical learning disability. Siswa tunagrahita adalah siswa yang mempunyai kemampuan intelektual di bawah ratarata (Pradhitya, Yunianta, \& Ratu, 2017). Siswa slow learner (lamban belajar) adalah siswa yang memiliki prestasi belajar rendah atau sedikit di bawah rata-rata dari anak normal pada umumnya, baik pada salah satu atau seluruh area akademik (Supriadi \& Damayanti, 2016). Siswa tunarungu memiliki keterbatasan dalam hal mendengar dikarenakan tidak berfungsinya organ-organ pendengaran, mereka tidak mampu memahami bentuk komunikasi audio dari lingkungan sekitarnya (Suningsih \& Arnidha, 2017). Siswa autis mempunyai kelainan perilaku yaitu tertarik pada aktivitas mentalnya sendiri (Bektiningsih, 2009). Siswa tunanetra memiliki penglihatan yang tidak berfungsi (blind/low vision) sebagai saluran penerima informasi dalam kegiatan sehari-hari (Desiningrum, 2016). Selanjutnya, persentase subjek dalam penelitian implementasi pembelajaran matematika pada ABK disajikan pada Gambar 2.

Kategori subjek dalam penelitian implementasi pembelajaran matematika pada ABK didominasi oleh siswa tunagrahita yaitu sebesar $41 \%$ dengan 7 artikel dari JME, JPM, Aksioma, dan Kreano. Pada jurnal Kreano, 75\% artikel menggunakan subjek siswa tunagrahita. Selanjutnya, siswa slow learner dengan persentase $23 \%$ dengan 4 artikel dari IJEME, Al-Jabar, Aksioma, dan Kreano. Persentase 18\% dari siswa tunarungu yang dipublikasikan oleh jurnal Aksioma, Pythagoras, dan Al-Jabar. Penelitian dengan subjek siswa tunanetra hanya terdapat 1 artikel pada jurnal Al-Jabar.
Selain itu, 1 artikel JRPM menggunakan subjek mathematical learning disability.
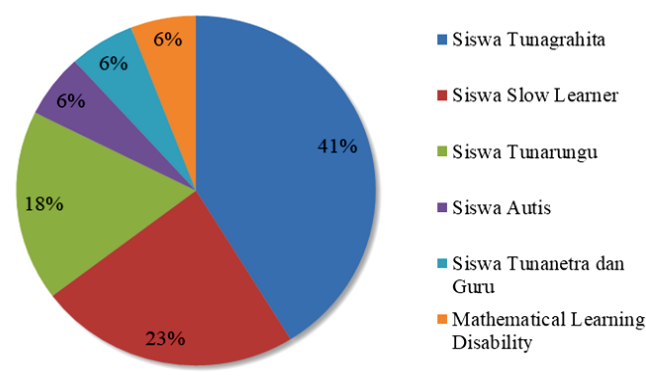

Gambar 2. Subjek dalam Penelitian

Implementasi Pembelajaran Matematika pada $\mathrm{ABK}$

\section{Jenjang Pendidikan dalam Penelitian Implementasi Pembelajaran Matematika pada ABK di Indonesia}

Menurut Undang-Undang

Republik Indonesia Nomor 20 Tahun 2003, jenjang pendidikan adalah tahapan pendidikan yang ditetapkan berdasarkan tingkat perkembangan peserta didik, tujuan yang akan dicapai, dan kemampuan yang dikembangkan. Pada pendidikan formal, jenjang pendidikan berupa pendidikan dasar, pendidikan menengah, dan pendidikan tinggi. Bentuk dari pendidikan dasar berupa sekolah dasar. Bentuk dari pendidikan menengah berupa sekolah menengah pertama dan sekolah menengah atas. Sedangkan bentuk dari pendidikan tinggi berupa perguruan tinggi.

Dalam penelitian implementasi pembelajaran matematika pada $\mathrm{ABK}$, bentuk jenjang pendidikan yang digunakan berupa sekolah dasar, sekolah menengah pertama, dan sekolah menengah atas. Persentase dari setiap jenjang pendidikan dalam penelitian implementasi pembelajaran matematika pada ABK di Indonesia, disajikan pada Gambar 3. 
DOI: https://doi.org/10.24127/ajpm.v10i3.3968

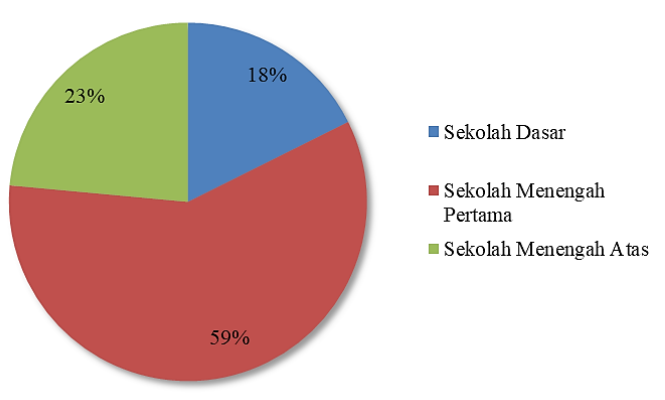

Gambar 3. Jenjang Pendidikan dalam Penelitian Implementasi Pembelajaran Matematika pada ABK

Gambar 3 menunjukkan bahwa sekolah menengah pertama mendominasi dengan persentase 59\% dengan 10 artikel. Sedangkan, pada sekolah menengah atas dengan 4 artikel, dan sekolah dasar dengan 3 artikel.

Dalam penelitian implementasi pembelajaran matematika pada $\mathrm{ABK}$, lembaga pendidikan yang digunakan yaitu Sekolah Luar Biasa dan Sekolah Inklusi. Terdapat 9 artikel terkait lembaga pendidikan Sekolah Luar Biasa, dan 8 artikel terkait lembaga pendidikan Sekolah Inklusi. Persentase hasil analisis artikel yang dikumpulkan terkait lembaga pendidikan yang digunakan dalam penelitian implementasi pembelajaran matematika pada ABK disajikan pada Gambar 4.

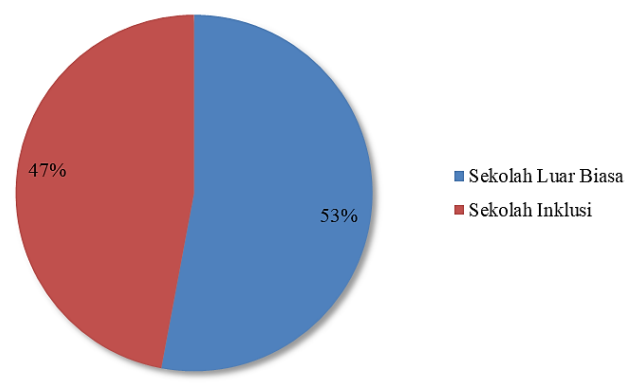

Gambar 4. Lembaga pendidikan yang digunakan dalam penelitian implementasi pembelajaran matematika pada ABK

\section{Materi dalam Penelitian Implementasi Pembelajaran Matematika pada ABK di Indonesia}

Matematika memiliki hubungan yang erat dalam kehidupan sehari-hari. Dengan mempelajari matematika, siswa akan terlatih kemampuan dalam berpikir logis, kritis, analitis, kreatif, dan aditif terhadap perubahan dan perkembangan jaman (Suningsih \& Arnidha, 2017).

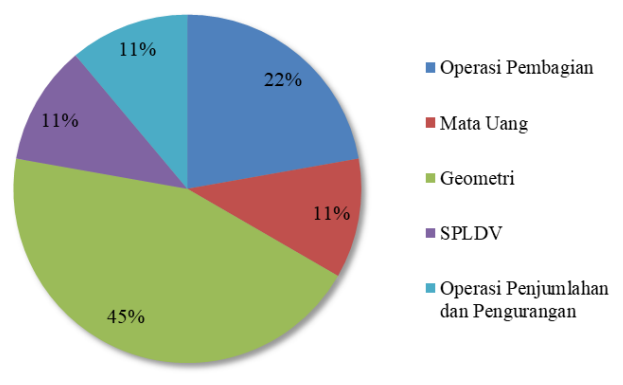

Gambar 5. Materi dalam penelitian implementasi pembelajaran matematika pada $\mathrm{ABK}$

Materi yang digunakan dalam penelitian-penelitian implementasi pembelajaran matematika pada $\mathrm{ABK}$ diantaranya operasi pembagian, operasi penjumlahan dan pengurangan, mata uang, SPLDV, dan geometri. Persentase hasil analisis artikel terkait materi dalam penelitian implementasi pembelajaran matematika pada $\mathrm{ABK}$ disajikan pada Gambar 5.

Materi geometri mendominasi dengan persentase $45 \%$. Geometri merupakan salah satu materi yang terdapat di tiap jenjang pendidikan, sehingga penting untuk dipelajari. Pentingnya mempelajari geometri diantaranya: (1) Geometri mampu memberikan pengetahuan yang lebih lengkap mengenai dunia; (2) Eksplorasi geometri dapat digunakan untuk mengembangkan kemampuan pemecahan masalah; (3) Geometri mendapat peran penting dalam mempelajari konsep lain pada pembelajaran matematika; (4) Geometri 
digunakan dalam kehidupan sehari-hari oleh banyak orang; (5) Geometri merupakan pelajaran yang menyenangkan (Nopriana, 2015). Cakupan geometri yang dibahas dalam penelitian pada jurnal Aksioma dan AlJabar berupa bangun datar untuk sekolah dasar. Sedangkan pada jurnal Pythagoras dan Kreano merupakan materi geometri pada jenjang sekolah menengah pertama.

Pada artikel di JPM, materi yang digunakan adalah mata uang. Pada materi mata uang, Standar Kompetensi yang digunakan adalah menggunakan mata uang dalam kegiatan sehari-hari, dengan Kompetensi Dasar: 1) Menghitung belanja; 2) Menghitung laba-rugi; 3) Menentukan harga jual dengan laba (Wahyuni, Hiltrimartin, \& Zulkardi, 2008).

Materi operasi pembagian dipublikasikan oleh JME dan jurnal Kreano. Jurnal Kreano juga mempublikasikan materi operasi penjumlahan dan pengurangan. Sedangkan, materi SPLDV dipublikasikan oleh jurnal Aksioma.

\section{Kemampuan Siswa yang menjadi Pembahasan dalam Penelitian Implementasi Pembelajaran Matematika pada ABK di Indonesia}

Salah satu tujuan yang terdapat dalam penelitian implementasi pembelajaran matematika pada $\mathrm{ABK}$ yaitu melihat beragam kemampuan siswa dalam matematika maupun nonmatematika. Prahmana, dkk (2020) menunjukkan bahwa kemampuan matematika dibagi menjadi 11 bagian, diantaranya: pemahaman matematika, komunikasi, koneksi, representasi, penalaran dan pembuktian, literasi matematika, berpikir kritis, berpikir kreatif, pemecahan masalah, disposisi, dan keterampilan intuitif. Sedangkan, kemampuan non matematika berdasarkan Taksonomi Bloom dan National Council of Teachers of Mathematics (NCTM) dibagi menjadi delapan bagian, diantaranya: karakter, aktivitas siswa, kemandirian belajar, efikasi diri, kinerja siswa, minat belajar, prestasi, dan kecerdasan intrapersonal.

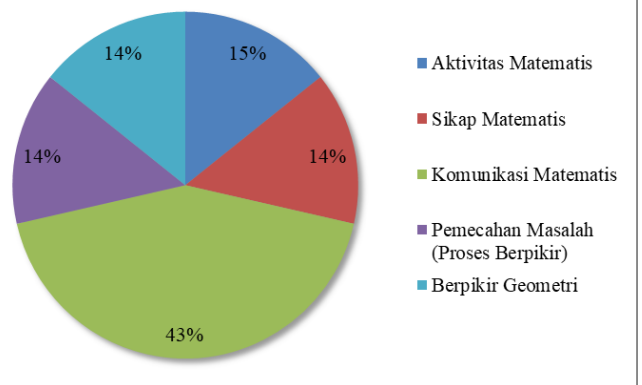

Gambar 6. Kemampuan siswa yang menjadi pembahasan dalam penelitian implementasi pembelajaran matematika pada ABK di Indonesia

Dalam penelitian implementasi pembelajaran matematika pada $\mathrm{ABK}$, kemampuan siswa yang digunakan diantaranya aktivitas, sikap matematis, komunikasi matematis, pemecahan masalah (proses berpikir), dan berpikir geometri. Persentase hasil analisis artikel terkait kemampuan siswa yang diteliti dalam penelitian implementasi pembelajaran matematika pada siswa ABK.

Gambar 6 menunjukkan bahwa komunikasi matematis mendominasi dengan persentase $43 \%$ yang dipublikasikan dalam jurnal Al-Jabar dan Aksioma dengan subjek siswa slow learner dan tunarungu. Kemampuan komunikasi matematis merupakan salah satu aktivitas sosial (talking) maupun alat bantu berpikir (writing) yang direkomendasi para pakar agar terus ditumbuhkembangkan dikalangan siswa (Umar, 2012). Pada kemampuan siswa aktivitas matematis, sikap matematis, pemecahan masalah (proses berpikir), 
dan berpikir geometri masing-masing memiliki persentase yang sama, dengan publikasi satu artikel. Pada penelitian Pradhitya, Yunianta, dan Ratu (2017), digunakan tingkatan Van Hiele untuk mengetahui profil berpikir geometri siswa.

\section{Metode Penelitian dalam Penelitian Implementasi Pembelajaran Matematika pada ABK di Indonesia}

Metode yang digunakan dalam penelitian implementasi pembelajaran matematika pada ABK diantaranya Studi Kasus, Deskriptif Kualitatif, Kualitatif, Eksperimen, Single Subject Research (SSR), Deskriptif, dan Research and Development (RnD) dengan menggunakan ADDIE, 4D, teori Borg \& Gall, dan teori Tessmer. Persentase hasil analisis artikel yang dikumpulkan terkait metode penelitian yang digunakan dalam penelitian implementasi pembelajaran matematika pada ABK disajikan pada Gambar 7.

Metode penelitian studi kasus mendominasi dengan persentase 23\% dengan 4 artikel. Studi kasus digunakan untuk mempelajari secara mendalam bagaimana individu atau kelompok melakukan sesuatu (Mujib, 2016). Sehingga, metode penelitian studi kasus cocok digunakan untuk lebih memahami ABK. Penelitian dengan metode studi kasus ini terdapat dalam jurnal Al-Jabar, JRAMathEdu, Aksioma, dan Kreano. Jika penelitian RnD dijumlahkan, maka persentasenya akan lebih tinggi dari metode studi kasus, karena jumlah artikelnya adalah 5. Penelitian RnD terdapat dalam JPM, JRPM, Pythagoras, dan Aksioma. Pengembangan yang dilakukan berupa bahan ajar dan media pembelajaran. Pada metode deskriptif kualitatif dipublikasikan dalam jurnal Al-Jabar, Aksioma, dan Kreano. Metode kualitatif dipublikasikan dalam jurnal Kreano dan Al-Jabar. Sedangkan pada penelitian eksperimen, SSR, dan penelitian deskriptif, dipublikasikan dalam IJEME, JME, dan Aksioma.

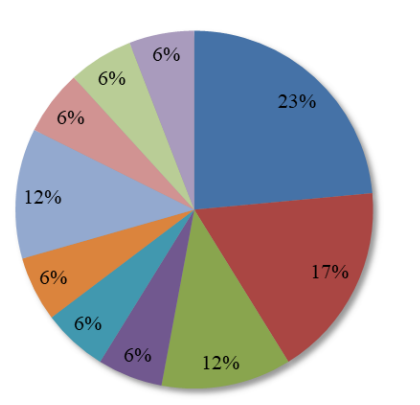

$$
\begin{aligned}
& \text { - Studi Kasus } \\
& \text { - Deskriptif Kualitatif } \\
& \text { — Kualitatif } \\
& \text { - Eksperimen } \\
& \text { - Single Subject } \\
& \text { - Research (SSR) } \\
& \text { - Deskriptif } \\
& \text { - RnD (ADDIE) } \\
& \text { - RnD (4D) } \\
& =\mathrm{RnD} \text { (Teori Borg \& } \\
& \mathrm{Gall)} \\
& -\mathrm{RnD} \text { (Teori Tessmer) }
\end{aligned}
$$

Gambar 7. Metode yang digunakan dalam penelitian implementasi pembelajaran matematika pada $\mathrm{ABK}$

\section{Artikel Penelitian Implementasi Pembelajaran Matematika Pada ABK di Indonesia}

Pada penelitian implementasi pembelajaran matematika pada $\mathrm{ABK}$ di Indonesia, terdapat 17 artikel yang termuat dalam 9 jurnal pendidikan matematika dan matematika yang telah terakreditasi oleh Kementrian Riset, Teknologi, dan Pendidikan Tinggi Republik Indonesia pada kategori Sinta 1 dan 2. Hal tersebut menandakan bahwa penelitian implementasi pembelajaran matematika pada $\mathrm{ABK}$ masih eksis, walaupun tidak terlalu mengalami peningkatan yang signifikan.

Subjek penelitian siswa tunagrahita mendominasi dengan lebih dari 30 persen penelitian implementasi pembelajaran matematika pada ABK di Indonesia. Sedangkan, materi geometri mendominasi dengan hampir 30 persen dari penelitian implementasi pembelajaran matematika pada ABK di Indonesia. Terdapat beberapa produk dihasilkan dalam penelitian pengembangan yaitu buku (Wahyuni, Hiltrimartin, \& Zulkardi, 2008), bahan ajar interaktif (Sumalasia, Suarsana, \& 
DOI: https://doi.org/10.24127/ajpm.v10i3.3968

Astawa, 2020), pocket book (Ariyantika, Farida \& Rakhmawati, 2019), modul (Wanabuliandari, Ristiyani, \& Kurniasih, 2020), dan media pembelajaran (Sari, Pratama, \& Permatasari, 2020).

\begin{abstract}
Pada Tabel 3, disajikan rangkuman pengelompokan artikel berdasarkan subjek penelitian yang dapat digunakan sebagai pedoman untuk mengkaji distribusi penelitian implementasi pembelajaran matematika pada ABK di Indonesia.
\end{abstract}

Tabel 3. Rangkuman penelitian implementasi pembelajaran matematika pada ABK di Indonesia

\begin{tabular}{|c|c|c|c|}
\hline No & Subjek & Materi/Topik & Referensi \\
\hline 1 & Tunagrahita & $\begin{array}{l}\text { Operasi Pembagian } \\
\text { Geometri } \\
\text { SPLDV } \\
\text { Operasi Penjumlahan } \\
\text { dan Pengurangan } \\
\text { Others }\end{array}$ & $\begin{array}{l}\text { (Nuari, Prahmana, \& Fatmawati, 2019; Nurfaidah, } \\
\text { Sudirman, \& Mellawaty, 2020) } \\
\text { (Pradhitya, Yunianta, \& Ratu, 2017) } \\
\text { (Suryadinata \& Farida, 2016) } \\
\text { (Sari, Pratama, \& Permatasari, 2020) } \\
\text { (Wahyuni, Hiltrimartin, \& Zulkardi, 2008; Ariyantika, } \\
\text { Farida \& Rakhmawati, 2019) }\end{array}$ \\
\hline 2 & Slow Learner & $\begin{array}{l}\text { Geometri } \\
\text { Others }\end{array}$ & $\begin{array}{l}\text { (Supriadi \& Damayanti, 2016; Wanabuliandari, } \\
\text { Ristiyani, \& Kurniasih, 2020) } \\
\text { (Putranto \& Marsigit, 2018; Aziz, Sugiman, \& } \\
\text { Prabowo, 2015) }\end{array}$ \\
\hline 3 & Tunarungu & $\begin{array}{l}\text { Geometri } \\
\text { Others }\end{array}$ & $\begin{array}{l}\text { (Sumalasia, Suarsana, \& Astawa, 2020) } \\
\text { (Mujib, 2016; Suningsih \& Arnidha, 2017) }\end{array}$ \\
\hline 4 & Autis & Others & (Sabaruddin, dkk, 2020) \\
\hline 5 & Tunanetra & Others & (Sadidah \& Wijaya, 2016) \\
\hline 6 & $\begin{array}{l}\text { Mathematical } \\
\text { learning } \\
\text { disability }\end{array}$ & Others & (Widyastuti, 2016) \\
\hline
\end{tabular}

\section{KESIMPULAN DAN SARAN}

Peneliti telah menganalisis 17 artikel yang ditampilkan di Tabel 3 dan mengklasifikasikan penelitian implementasi pendidikan matematika pada ABK di Indonesia dalam beberapa kategori, diantaranya subjek, jenjang pendidikan, materi, kemampuan siswa, serta metode yang digunakan dalam penelitian-penelitian implementasi pembelajaran matematika pada $\mathrm{ABK}$.

Subjek penelitian implementasi pembelajaran matematika pada $\mathrm{ABK}$ di Indonesia yang sering diteliti yaitu siswa tunagrahita, dengan jenjang pendidikan sekolah menengah dilanjutkan dengan sekolah dasar. Peneliti menyarankan, untuk selanjutnya penelitian dapat dilakukan pada tingkatan lain, seperti perguruan tinggi, dan dengan subjek penelitian yang lebih beragam. Materi yang sering digunakan dalam penelitian implementasi pembelajaran matematika pada ABK di Indonesia yaitu geometri, karena penggambarannya sangat mudah ditemukan dalam kehidupan sehari-hari. Cabang matematika cukup banyak, seperti aljabar dan statistika, sehingga dapat dijadikan pilihan untuk penelitian selanjutnya agar lebih beragam.

Kemampuan siswa yang sering digunakan dalam penelitian implementasi pembelajaran matematika pada ABK di Indonesia yaitu komunikasi matematis, yang berhubungan dengan aktivitas sosial siswa. Sedangkan, metode yang sering digunakan yaitu studi kasus dan penelitian pengembangan. Pada 
penelitian pengembangan, para peneliti dapat menciptakan sesuatu yang bermanfaat bagi pembelajaran matematika dan mempermudah siswa ABK dalam mempelajari matematika, walaupun memiliki keterbatasan. Terakhir, penelitian ini berkontribusi dalam memberikan informasi terkait tren penelitian pendidikan matematika pada ABK, berupa subjek, jenjang pendidikan, materi, kemampuan siswa, serta metode yang digunakan dalam penelitian-penelitian implementasi pembelajaran matematika pada $\mathrm{ABK}$, sehingga menjadi rekomendasi dan ide untuk penelitian selanjutnya.

\section{DAFTAR PUSTAKA}

Ariyantika, D., Farida, \& Rakhmawati, R. (2019). Pengembangan Pocket Book of Mathematic pada Siswa Berkebutuhan Khusus untuk Memfasilitasi Kemampuan Pemahaman Konsep Matematis. Aksioma: Jurnal Program Studi Pendidikan Matematika, 8(1), 175-183.

Aziz, A. N., Sugiman, \& Prabowo, A. (2015). Analisis Proses Pembelajaran Matematika pada Anak Berkebutuhan Khusus (ABK) Slow Learner di Kelas Inklusif SMP Negeri 7 Salatiga. Kreano, 6(2), 111-120.

Bektiningsih, K. (2009). Program Terapi Anak Autis di SLB Negeri Semarang. Jurnal Kependidikan, 39(2), 95-110.

Calderón, A., \& Ruiz, M. (2015). A systematic literature review on serious games evaluation: An application to software project management. Computers \& Education, 87, 396-422.

Desiningrum, D. R. (2016). Psikologi Anak Berkebutuhan Khusus. Yogyakarta: Psikosain.
Lusiana, L., \& Suryani, M. (2014). Metode SLR untuk mengidentifikasi isu-isu dalam Software Engineering. SATIN (Sains Dan Teknologi Informasi), 3(1), 1-11.

Mujib. (2016). Komunikasi Matematis Siswa Tunarungu dalam Pembelajaran Matematika Didasarkan pada Teori Schoenfeld. Al-Jabar: Jurnal Pendidikan Matematika, 7(1), 8590.

Nopriana, T. (2015). Disposisi Matematis Siswa Melalui Model Pembelajaran Geometri Van Hiele. Fibonacci: Jurnal Pendidikan Matematika \& Matematika, 1(2), 80-94.

Nuari, L. F., Prahmana, R. C. I., \& Fatmawati, I. (2019). Learning of Division Operation for Mental Retardations' Student Through Math Gasing. Journal on Mathematics Education, 10(1), 127-142.

Nurfaidah, Sudirman, \& Mellawaty. (2020). Bagaimanakah Cara Siswa Tunagrahita Ringan Menyelesaikan Soal Operasi Hitung Pembagian?: Exploratory Case Study dalam menggunakan Media Kotak Puzzle Geometri. Kreano, 11(2), 143-152

Pradhitya, R. F., Yunianta, T. N. H., \& Ratu, N. (2017). Profil Berpikir Geometri Siswa Tunagrahita berdasarkan Tingkatan Van Hiele di SMPLB Negeri Salatiga. Kreano, 8(1), 85-93.

Prahmana, R. C. I., Sagita, L., Hidayat, W., \& Utami, N. W. (2020). Two Decades of Realistic Mathematics Education Research in Indonesia: A Survey. Infinity Journal, 9(2), 223-246. 
Pratama, R. A. (2018). Media Pembelajaran Berbasis Articulate Storyline 2 Pada Materi Menggambar Grafik Fungsi di SMP Patra Dharma 2 Balikpapan. Dimensi, 7(1), 19-35.

Putranto, S., \& Marsigit. (2018). Is it Effective using Peer Tutoring with Realistic Mathematics Education Approach to Improve Slow Learners' Mathematics Attitudes?. International Journal on Emerging Mathematics Education, 2(2), 179-186.

Ramdani, Y. (2006). Kajian Pemahaman Matematika Melalui Etika Pemodelan Matematika. Mimbar, 22(1), 1-14.

Rastuti, M., \& Prahmana, R. C. I. (2021). The Programme for International Student Assessment Research in Indonesia. Jurnal Elemen, 7(2), 232-253.

Sabaruddin, S., Mansor, R., Rusmar, I., \& Husna, F. (2020). Student with special needs and mathematics learning: A case study of an autistic student. JRAMathEdu (Journal of Research and Advances in Mathematics Education), 5(3), 317-330.

Sadidah, A., \& Wijaya, A. (2016). Developing Mathematics Learning Set for Special-Needs Junior High School Student Oriented to Learning Interest and Achievement. Jurnal Riset Pendidikan Matematika, 3(2), 150-161.

Sari, L., Pratama, R. A., \& Permatasari, B. I. (2020). Media Pembelajaran Puzzle Angka dan Corong Angka (PANCORAN) Bagi Anak Berkebutuhan Khusus (ABK). Kreano, 11(1), 88-100.

Simatupang, E., \& Yuhertiana, I. (2021). Merdeka Belajar Kampus
Merdeka terhadap Perubahan Paradigma Pembelajaran pada Pendidikan Tinggi: Sebuah Tinjauan Literatur. Jurnal Bisnis, Manajemen, dan Ekonomi, 2(2), 30-38.

Sujana, I. W. C. (2019). Fungsi dan tujuan pendidikan Indonesia. Adi Widya: Jurnal Pendidikan Dasar, 4(1), 29-39.

Sumalasia, K. Y., Suarsana, I. M., \& Astawa, I. W. P. (2020). Pengembangan Bahan Ajar Interaktif Multi Representasi Pada Materi Geometri Kelas VII SMPLB Tunarungu. PYTHAGORAS: Jurnal Pendidikan Matematika, 15(1), 36-47.

Suningsih, A. \& Arnidha, Y. (2017). Komunikasi Matematis Siswa Tunarungu Melalui Model Pembelajaran Think Pair Share. Aksioma: Jurnal Program Studi Pendidikan Matematika, 6(3), 375-384.

Supriadi, N., Damayanti, R. (2016). Analisis Kemampuan Komunikasi Matematis Siswa Lamban Belajar dalam Menyelesaikan Soal Bangun Datar. Al-Jabar: Jurnal Pendidikan Matematika, 7(1), 19.

Suryadinata, N., \& Farida, N. (2016). Analisis Proses Berpikir Anak Berkebutuhan Khusus (ABK) dalam Menyelesaikan Masalah Matematika di SMP Inklusi Kota Metro (Studi Kasus pada Siswa Tunagrahita Ringan). Aksioma: Jurnal Program Studi Pendidikan Matematika, 5(1), 94-104.

Umar, W. (2012). Membangun Kemampuan Komunikasi Matematis dalam Pembelajaran Matematika. Infinity, 1(1), 1-9 
DOI: https://doi.org/10.24127/ajpm.v10i3.3968

Undang-Undang Republik Indonesia Nomor 20 Tahun 2003.

Wahyuni, N., Hiltrimartin, C. \& Zulkardi. (2008). Pengembangan Materi Pokok Mata Uang dengan Pendekatan PMRI untuk Siswa Tunagrahita Ringan Kelas XI di SLBC Karya Ibu Palembang. Jurnal Pendidikan Matematika, 2(1), 1-12.

Wanabuliandari, S., Ristiyani, \& Kurniasih, N. (2020). Desain Pengembangan Modul Matematika Berbasis Santun Berbahasa untuk Siswa Slow Learner di Sekolah Dasar. Aksioma: Jurnal Program Studi Pendidikan Matematika, 9(3), 601-616.

Widyastuti, R. (2016). Pola Interaksi Guru dan Siswa Tunanetra SMPLB A Bina Insani Bandar Lampung. Al-Jabar: Jurnal Pendidikan Matematika, 7(2), 257-266.

Yunanto, A. A. \& Rochimah, S. (2017). Systematic Literature Review Terhadap Evaluasi Perangkat Lunak Tentang Serious Game. Jurnal Informatika, 4(1), 54-65. 